\title{
Reduction of the allergenicity of cow's milk $\alpha$-lactalbumin under heat-treatment and enzymatic hydrolysis in Moroccan population
}

Laboratory of Bioactive Molecules (LBM), Faculty of Sciences and Technology, Sidi Mohamed Ben Abdellah University, Fez, Morocco

\section{KeY WORDS}

serial IgE; $\alpha$-lactalbumin; heattreatment; pepsin hydrolysis; epitopes

\section{Corresponding author}

Lotfi Aarab

Laboratory of Bioactive Molecules

Faculty of Sciences and Techniques

P.O. Box 2202

Road of Immouzer, Fez, Morocco

Fax: +212535608214

E-mail: aarablmbsf@gmail.com

\section{DOI}

10.23822/EurAnnACI.1764-1489.60

\begin{abstract}
Summary
The aim of the present study is to evaluate the effect of heat-treatment and enzymatic hydrolysis on the allergenicity of cow's milk $\alpha$-lactalbumin $(\alpha-L A)$ in a Moroccan population. A total of 557 patients were recruited from the University Hospital Complex and the Ibn El Khatib Hospital of Fez city. This population consented to realize a dosage of IgE levels to raw cow milk and then to $\alpha-L A$ native and treated with the studied treatments. The results revealed that $54.4 \%$ of the studied subjects presented positive values of serial IgE to raw cow milk. The effect of treatments on the allergenicity of $\alpha-L A$ showed that heat-treatment at $90^{\circ} \mathrm{C}$ and pepsin hydrolysis at $37^{\circ} \mathrm{C}$, for 1 hour each, caused an important decrease in the IgE binding with an average of reduction of $59 \%$ and $74 \%$, respectively.
\end{abstract}

\section{Introduction}

Cow's milk is the first component introduced into the diet, and it is the most common cause of food allergy in the World. In Morocco, cow's milk allergy is about $6.9 \%$ in schoolchildren (1) and between $2 \%$ to $3.6 \%$ in general population $(2,3,4)$.

Several studies have identified casein as a major cow milk allergen that induces strong immediate allergic reactions $(5,6,7)$. $\beta$-Lactoglobulin represents another important cow milk allergen that is recognized by milk allergic patients $(8,9)$. However, for $\alpha$-lactalbumin, a widely varying sensitivity has been reported in the literature $(10,5)$.

The $\alpha$-lactalbumin is a $14.2 \mathrm{kDa}$ calcium binding protein, which plays an important role in the biosynthesis of lactose through the interaction with lactose synthase (11). It is expressed exclusively during lactation in the mammary gland and accounts for $20 \%$ of bovine whey proteins (12).
Different studies have been reported concerning the effect of treatments on the allergenicity of cow's milk proteins, indicating either a decrease or an increase in the sensitivity of patients $(13,14,15,16,4)$. However, studies about the modification of allergenicity of $\alpha$-lactalbumin were limited.

From the above, the purpose of this research is to determine the effect of thermal treatment and enzymatic hydrolysis on the antigenicity as well as the allergenicity of $\alpha$-lactalbumin in a population from Fez-Meknes region of Morocco, using ELISA and Dot-blot assay.

\section{Materials and methods}

Collect of patient's sera

A transversal study was conducted in public and private laboratories of Fez-Meknes Hospitals, in order to collect information 
about milk sensitivity as well as blood serum samples. Before any serum sample taking, a questionnaire was carefully completed with each patient, and a formal consent of each patient or of the children's parents was signed. The questionnaire contains data relating to age, sex and if there were any possible reaction to milk. Then, the collected sera were centrifuged at $3000 \mathrm{rpm} / 5 \mathrm{~min}$ and stored at $-20{ }^{\circ} \mathrm{C}$ until use. The patients had not been sensitized beforehand with regards to milk proteins. They were patients who came for different medical tests, and they accepted to participate in the study benevolently. This study was approved by the ethic committee of the University Hospital Center of Fez.

\section{Extraction of $\alpha$-lactalbumin}

The extraction of $\alpha$-lactalbumin was realized according to Wal et al. (1995) (5) with some adjustments. In fact, a volume of $100 \mathrm{ml}$ of raw cow's milk was skimmed, its $\mathrm{pH}$ was adjusted to $4.6 \mathrm{by} \mathrm{HCl}(3 \mathrm{~mol} / \mathrm{l})$ and centrifuged at $5000 \mathrm{rpm} / 20 \mathrm{~min}$. The whey proteins fraction was extracted in the supernatant, and dialyzed against bi-distilled water. The dialyzed extract was separated using gel filtration (G-100 Sephadex) column and the absorbance of fractions (50 fractions; $2 \mathrm{ml}$ per tube) was determinated by an UV-Visible Spectrometer at $280 \mathrm{~nm}$. The fraction presenting $\alpha-L A$ was then concentrated in a $10 \%$ polyethylene glycol solution (PEG). The quality of protein extracted was characterized by sodium dodecylsulphate-polyacrylamide gel electrophoresis (SDS-PAGE).

\section{SDS-PAGE of $\alpha$-lactalbumin}

SDS-PAGE was performed under denaturation conditions in $20 \%$ polyacrylamide gel. A volume of $100 \boldsymbol{\mu l}$ of the purified $\alpha$-LA was mixed with loading buffer (10\% SDS, $10 \%$ glycerol, $10 \% \beta$-mercaptoethanol, and $2.5 \%$ bromphenol blue) and heated at $100^{\circ} \mathrm{C}$ for $5 \mathrm{~min}$. Then, the gel was fixed and stained using Coomassie Brilliant Blue R-250 (0.1\%).

\section{Dot-blot assay}

Dot-blot assay was realized as described before (3). Briefly, 5 $\mu \mathrm{l}$ of purified $\alpha$-LA was spotted on nitrocellulose membranes and incubated at $37^{\circ} \mathrm{C}$ for 2 hours. Then, the dried spotted membranes were saturated by borate buffered saline (BBS) containing $2.5 \%$ Tween- 20 for $1 \mathrm{~h}$ at $37^{\circ} \mathrm{C}$, in order to block the non-specific binding sites. Afterward, the membranes were incubated with human sera overnight at $4{ }^{\circ} \mathrm{C}$, and later with anti-IgE peroxidase conjugate for $1 \mathrm{~h}$ at $37^{\circ} \mathrm{C}$. Finally, the reaction was revealed by the incubation of membranes in a solution containing $0.05 \%$ of diaminobenzidine (DAB) in BBS tampon. As indication, after each incubation step, the membranes were washed 3 times by BBS containing $0.1 \%$ Tween- 20 .

\section{Heat-treatment and pepsin hydrolysis}

The treatment of $\alpha$-LA was performed on three sets of experiments; the first one was heat-treatment conducted in a thermostatic water bath $\left(70,80\right.$, and $\left.90^{\circ} \mathrm{C}\right)$ for 30,60 , and $120 \mathrm{~min}$, the second one was pepsin hydrolysis (hog stomach, $3354 \mathrm{U} /$ $\mathrm{mg}$ ) at a concentration of $50 \mu \mathrm{g} / \mathrm{ml}$ in an acidic medium $(\mathrm{pH}=$ 2) during 30,60 and $120 \mathrm{~min}$ at $37^{\circ} \mathrm{C}$, and the third one was the combination of the two treatments, heat-treatment followed by enzymatic digestion.

\section{Production of polyclonal antibodies anti $\alpha$-lactalbumin}

Anti $\alpha$-LA antibodies were prepared by immunizing rabbits against the native protein $(\alpha-\mathrm{LA})$ using Freund adjuvant. After five weeks, animals were sacrificed according to National Ethical Laws and blood samples were collected in dry tubes. After centrifugation for 15 minutes at $3000 \mathrm{rpm}$ at $4{ }^{\circ} \mathrm{C}$, serum was separated and frozen at $-20^{\circ} \mathrm{C}$ until use.

\section{Specific IgE determination}

In order to determine levels of specific IgE to milk and $\alpha$-LA, indirect ELISA was used as described beforehand $(17,18,4)$. Firstly, $100 \mu$ of skimmed raw milk or $\alpha$-LA $(0.5 \mathrm{mg} / \mathrm{ml})$ in PBS (Phosphate Buffered Saline, $\mathrm{pH}$ 7.4) was deposited on the wells of micro-titration plate ( $100 \mu \mathrm{l} /$ well). Next, wells were saturated by BBS (borate buffered saline, $\mathrm{pH} 8.4$ ) containing $2.5 \%$ Tween 20 , and $100 \mu \mathrm{l}$ of the human serum added. The revelation was made by adding the anti-human $\mathrm{IgE}$ conjugated to peroxidase, followed by addition of the ortho-phenylenediamine (OPD $0.05 \%)$ substrate. After incubation at $37^{\circ} \mathrm{C}$ during $20 \mathrm{~min}$, the reaction was stopped by adding $50 \mu \mathrm{l}$ of $\mathrm{HCl}(3 \mathrm{~mol} / \mathrm{l})$ and the absorbance was measured at $490 \mathrm{~nm}$ by an ELISA reader.

\section{Statistical analysis}

Descriptive statistics were presented as numbers with percentages or as average values. Statistical analysis was based on the student's t-test taking $\mathrm{p}<0.05$ as the limit of significant value. All statistical analyses were performed using Excel software.

\section{Results}

The questionnaire was fulfilled in by 832 subjects, represented by $54.5 \%$ of men and $45.4 \%$ of women. The age of the studied population ranged between 2 and 60 years old, among whom $18.8 \%$ were children ( $2-20$ years) and $80.2 \%$ were adults (2060 years).

Adverse reaction to milk was reported by $3.6 \%$ of the studied population, where children (2-10 years) and adults (20-40 
Figure 1 - Electrophoresis profile of $\alpha$-lactalbumin. 1, native $\alpha-L A ; 2, \alpha-L A$ processed by heat-treatment; $3, \alpha-L A$ hydrolyzed by pepsin; 4, $\alpha-L A$ treated by heat followed by pepsin hydrolysis. $M$, Molecular weight marker.

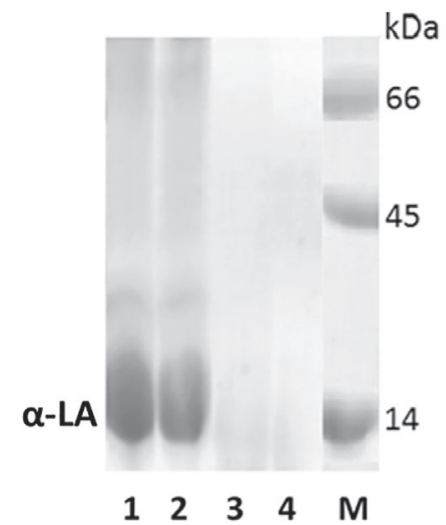

years) were the populations reporting most sensitivity to milk, with $4 \%$ and $4.3 \%$, respectively. The clinical signs mostly reported by our studied population were gastrointestinal reactions (73\%), followed by cutaneous reactions $(13 \%)$ and respiratory symptoms (6.6\%).

The dosage of specific IgE to raw cow milk showed that $54.4 \%$ (303/557) presented positive values ranging from 2.7 to 595.2 $\mathrm{IU} / \mathrm{ml}$, with an average of $95.2 \mathrm{IU} / \mathrm{ml}$. Among this population, $17.2 \%(\mathrm{n}=96)$ presented values more than $100 \mathrm{IU} / \mathrm{ml}, 6.6 \%(\mathrm{n}$ = 37) more than $200 \mathrm{IU} / \mathrm{ml}$ and $4.6 \%(\mathrm{n}=25)$ more than 250 $\mathrm{IU} / \mathrm{ml}$. For adults, the average of IgE levels was $101.2 \mathrm{IU} / \mathrm{ml}$, ranging from $1.91 \mathrm{IU} / \mathrm{ml}$ to $595.25 \mathrm{IU} / \mathrm{ml}$, while the children population presented an average of IgE levels of $85.3 \mathrm{IU} / \mathrm{ml}$, ranging from $2.75 \mathrm{IU} / \mathrm{ml}$ to $557.75 \mathrm{IU} / \mathrm{ml}$. Regarding gender, the average of positive values of specific IgE levels was approximately the same; $97.96 \mathrm{IU} / \mathrm{ml}$ represented by men and 94.87 $\mathrm{IU} / \mathrm{ml}$ represented by women.

\section{Electrophesis of $\alpha$-lactalbumin}

The results of extracted $\alpha$-LA native and treated by different treatments were presented in figure 1 . The band of $\alpha$-LA corresponded to a molecular weight of $14 \mathrm{kDa}$. The treatment of this protein by heat at $90{ }^{\circ} \mathrm{C}$ for 1 hour showed a very slight reduction in its band, but when it underwent pepsin hydrolysis for 1 hour with or without previous heating, the band totally disappeared.

Effect of heat-treatment and pepsin hydrolysis on the detection of $\alpha-L A$ by rabbit IgG by means of ELISA and Dot-blot assay

In order to determine the parameters of reduction of the immunoreactivity of $\alpha$-LA to specific antibodies, we firstly studied its recognition by rabbit IgG anti- $\alpha$-LA under heat-treatment, pepsin hydrolysis and under their combination. Under treatment by temperature (figure 2), the detection of $\alpha$-LA was reduced after heating within $30 \mathrm{~min}$ at different temperatures, and was slightly modified for more heating time. Temperatures of $80^{\circ} \mathrm{C}$ and $90^{\circ} \mathrm{C}$ highly changed the liaison to $\mathrm{IgG}$, more than $70{ }^{\circ} \mathrm{C}$. Maximal reduction of IgG binding to $\alpha$-LA were: $74 \%$ at $70{ }^{\circ} \mathrm{C}, 94 \%$ at $80{ }^{\circ} \mathrm{C}$, and $97 \%$ at $90{ }^{\circ} \mathrm{C}$. Concerning the hydrolysis by pepsin, we noticed that the detection of $\alpha$-LA decreased progressively, until it reached a rate of $62 \%$ of decrease after $120 \mathrm{~min}$ of hydrolysis. While, when the two treatments were used, the detection of this protein by $\operatorname{IgG}$ was highly

Figure 2 - Effect of heat-treatment on $\alpha$-LA binding to rabbit IgG.

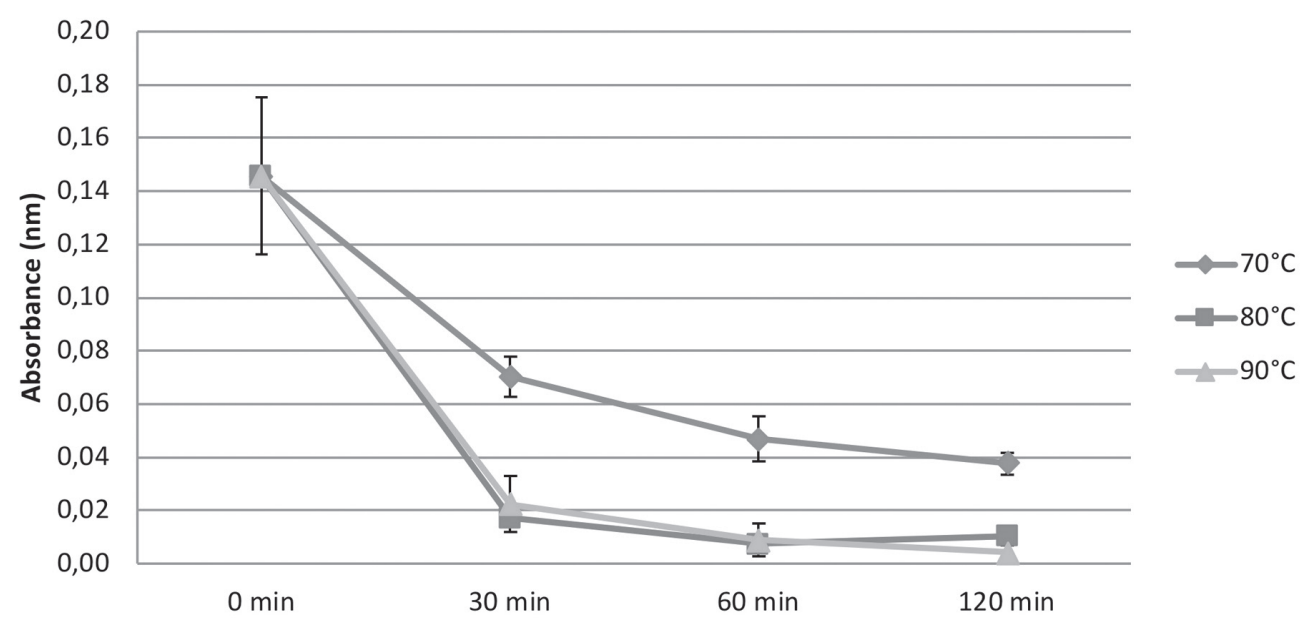


Figure 3 - Effect of heat-treatment and pepsin hydrolysis on the recognition of $\alpha$-LA by rabbit IgG.

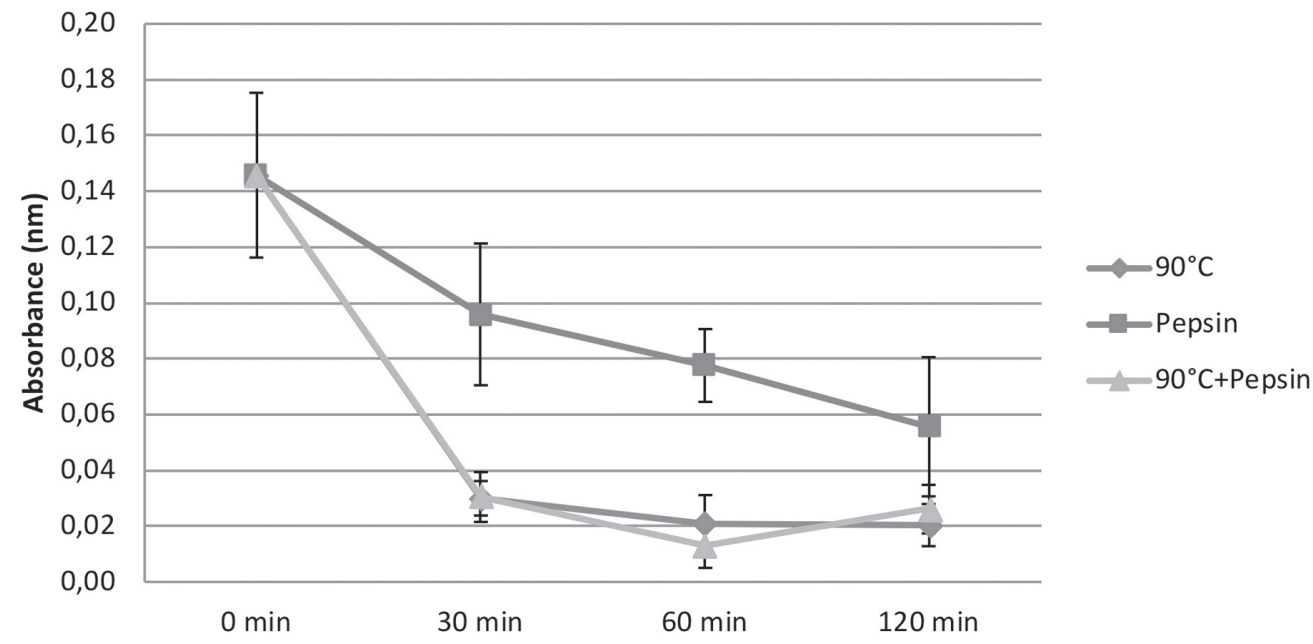

Figure 4 - Dot-blot assay of $\alpha-L A$ with rabbit IgG anti native $\alpha$-lactalbumin. 1, Dot-blot of native $\alpha-L A ; 2$, Dot-blot of $\alpha-L A$ processed by heat-treatment; 3, Dot-blot of $\alpha$-LA treated by pepsin; 4, Dot-blot of $\alpha-L A$ treated by heat followed by pepsin hydrolysis.

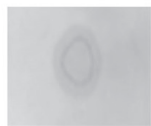

1

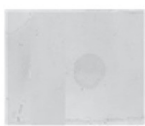

2

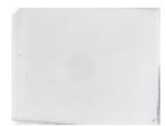

3

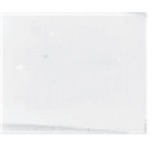

4 attenuated within 60 min of treatment, reaching a maximum of 91\% of reduction (figure 3 ).

Similar results were observed using the Dot-blot assay. The presence of the blotting spot indicated that native $\alpha$-LA reacted to $\mathrm{IgG}$. However, when $\alpha$-LA underwent different treatments for $60 \mathrm{~min}$ each, its recognition by IgG was modified. This modification was slight under heat-treatment for $60 \mathrm{~min}$, while it was more important under pepsin hydrolysis as well as under the combination of treatments (figure 4).

Figure 5 - Effect of heat-treatment and pepsin hydrolysis on the recognition of $\alpha$-LA by human $\operatorname{IgE}$.

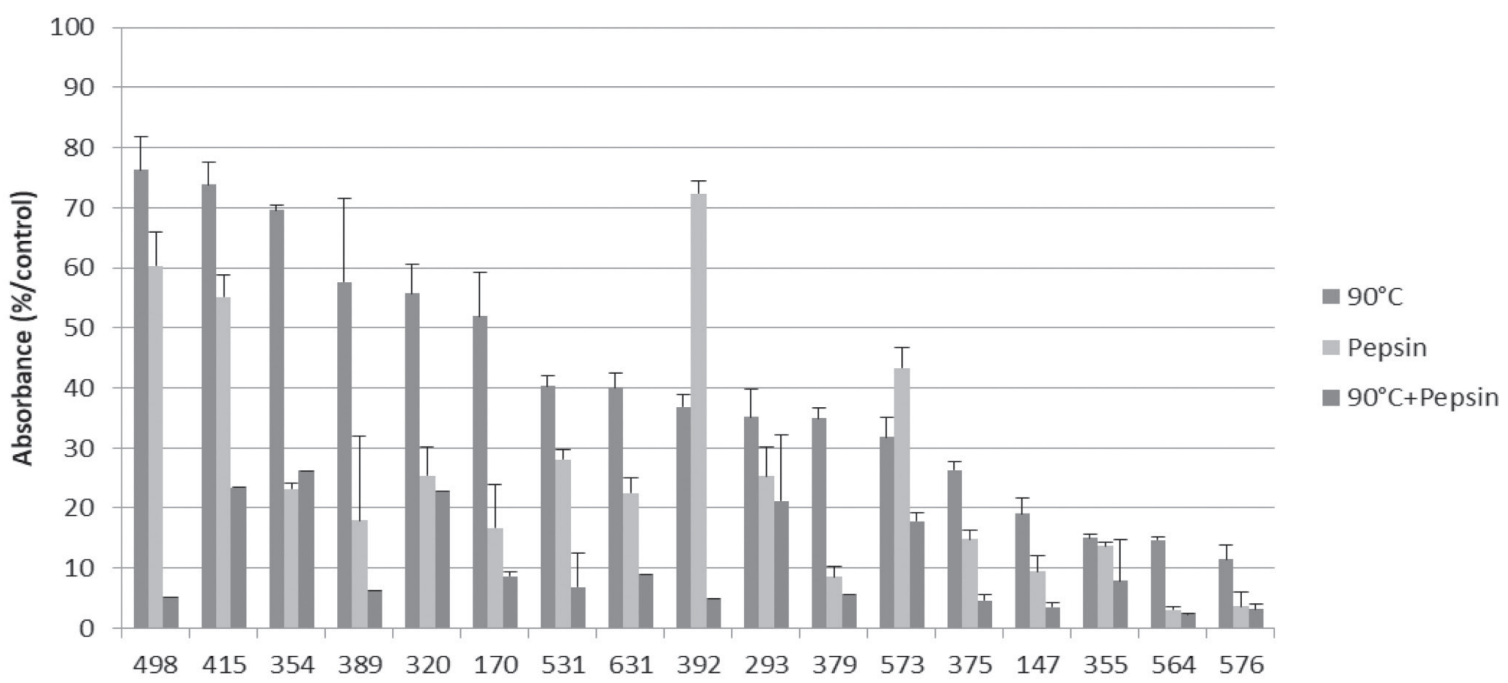


Effect of heat-treatment and pepsin hydrolysis on the detection of $\alpha-L A$ by human IgE by means of ELISA and Dot-blot assay

Sera of 17 patients presenting high levels of $\operatorname{IgE}$ to $\alpha$-LA (> 90 $\mathrm{IU} / \mathrm{ml}$ ) were used to study the effect of treatments on the recognition of $\alpha$-LA by human IgE basing on ELISA. The results showed that under heat-treatment at $90^{\circ} \mathrm{C}$ during $60 \mathrm{~min}$, all patients showed an important decrease in the recognition of heated $\alpha$-LA. This reduction was more than $50 \%$ for 11 patients, with a maximum of $88 \%$ and an average of reduction of $59 \%$.

Under pepsin hydrolysis, the results showed that all patients presented high reduction in the recognition of treated $\alpha$-LA. This reduction was varying from $27 \%$ to $96 \%$, and it was more than $40 \%$ for $82 \%$ of studied patients $(n=14$ from 17$)$. The average of this reduction was $74 \%$.

In the same manner, high decrease reactivity to treated $\alpha$-LA by a combination of heat-treatment and pepsin hydrolysis was observed for all studied patients, with an average of $89 \%$ and a maximum of $97 \%$. Also, $82 \%$ of patients presented a significant decrease in the recognition of $\alpha$-LA when the treatments were combined more than each one solely (figure 4).

Basing on Dot-blot assay, sera of 14 patients with high specific IgE levels to $\alpha$-LA (> $65 \mathrm{IU} / \mathrm{ml}$ ) were tested. The presence of spots indicated that all these patients reacted to native $\alpha$-LA. Thus, their sera were used to study their reactivity to treated $\alpha$-LA. The results showed that the intensity of the spots highly decreased when the protein was processed by heat-treatment for almost all patients, except two of them (14 and 17) still reacting to heated $\alpha-\mathrm{LA}$. As regards the pepsin hydrolysis and the combination of the two treatments, we remarked an absence of spots under the two treatments, indicating that the allergenicity of $\alpha$-LA was strongly attenuated for all studied subjects (figure 6).

\section{Discussion}

This research aimed to determine the effect of thermal treatment and enzymatic hydrolysis on the allergenicity of $\alpha$-lactalbumin in a population from Fez-Meknes region of Morocco using ELISA and Dot-blot assay.

Our results showed that $3.6 \%$ of our population reported sensitivity to milk. We remarked that milk allergy was mostly reported in our studied population by children of less than 10 years and by adults of 20-40 years old. This result is in accordance with previous works concerning food allergy in Morocco, where our team research was involved $(2,3,4,19)$.

Regarding specific IgE levels to cow milk, the results showed a strong sensitivity of the studied population to cow milk, especially in adult population aged $20-40$ years. Therefore, we screened 31 sera sample presenting high levels of specific $\operatorname{IgE}$ to cow milk $\alpha$-LA, in order to study the effect of thermal and enzymatic treatments on the allergenicity of $\alpha$-lactalbumin.

Results showed that treatment by temperature reduced slightly $\alpha$-LA band profile, while we observed by ELISA a high reduction in the IgE binding to heated $\alpha$-LA for $70 \%$ of tested patients. This reduction presented an average of $59 \%$, and varied from $23 \%$ to $88 \%$. This result was confirmed by Dot-blot assay. This finding suggests that our studied population presented mostly conformational epitopes which has been reported to be denaturized under heat-treatment $(20,21,22,4)$. Our results showed that the allergenicity of $\alpha$-LA was decreased in all patients, and this decrease varied between $11 \%$ and $80 \%$, indicating that there is a residual reactivity to heated $\alpha$-LA persisted in some patients. This result of decreased allergenicity was in line with works of Bloom et al. (2014) (23) and Xu et al. (2015) (24), while the important residual allergenicity found is in ac-

Figure 6 - Results of Dot-blot assay with sera of 14 patients. A, Dot-blot of native $\alpha$-LA; B, Dot-blot of $\alpha$-LA processed by heat-treatment; $C$, Dot-blot of $\alpha-L A$ treated by pepsin; $D$, Dot-blot of $\alpha$-LA treated by heat followed by pepsin hydrolysis.

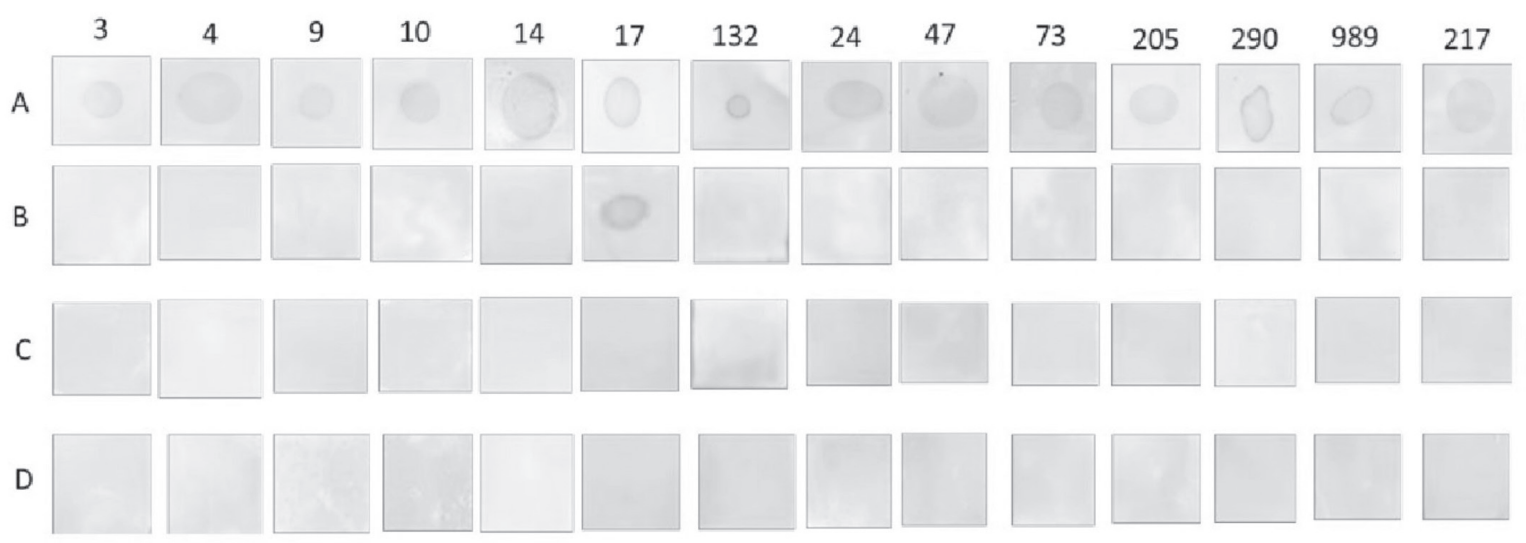


cordance with a study of Lee et al. (2014) (25). This difference in results might be explained by the differences in studied subjects, as well as by heterogeneity in the method of study as these previous works based on pooled sera, while our study was done using individual sera and purified $\alpha$-LA.

The results of pepsin hydrolysis exhibited the disappearance of $\alpha$-LA band in SDS-PAGE profile, accompanied with an important decrease in rabbit IgG binding as well as in human $\mathrm{IgE}$ binding antibodies. This finding showed that $\alpha$-LA lost its allergenic effect under pepsin hydrolysis, as it was reported in previous works $(26,22,4)$. Regarding the antigenicity of hydrolyzed $\alpha$-LA, our result was in line with the study of Kim et al. (2007) (27) who found that the antigenicity of $\alpha$-LA decreased significantly when the concentrate of whey proteins was hydrolyzed by pepsin. Concerning the treatment by heat-treatment followed by pepsin hydrolysis, the binding to $\operatorname{IgE}$ antibodies was totally attenuated. This attenuation reached a maximum of $97 \%$ of the protein allergenicity. All studied subjects showed a significant decrease in $\operatorname{IgE}$ binding to treated $\alpha$-LA under the combination of treatments which was more predominant than under each treatment solely (heat or hydrolysis). This indicated that the pre-heating may ameliorate the enzymatic action, as was reported previously (28).

These findings indicate that the majority of studied subjects recognize conformational epitopes, as there was an important decrease in the $\mathrm{IgE}$ binding after heat-treatment, while some patients showed slight decrease in $\operatorname{IgE}$ binding indicating that they recognize mostly linear epitopes. Furthermore, the pepsin hydrolysis alone or preceded by heat-treatment, caused an important decrease in the recognition of $\alpha$-LA for all studied subjects. However, in previous works of our laboratory, the pepsin hydrolysis preceded by heat showed an apparition of new epitopes $(18,2,3,22,4)$.

\section{Conclusion}

In conclusion, our study focused on the effect of heat-treatment and pepsin hydrolysis on the allergenicity of cow milk $\alpha$-LA as one of allergens incriminated in milk allergy. The results showed that milk allergy could be related to $\alpha$-LA sensitivity. We observed that there was a significant decrease in the $\alpha$-LA allergenicity after heating and with hydrolyzed $\alpha$-LA in all studied subjects. This indicated the implication of conformational epitopes in this allergenicity. Furthermore, the residual reactivity of $\mathrm{IgE}$ to heated $\alpha$-LA, indicated that sequential epitopes were also implicated in the sensitivity of this population, but at less level.

\section{Acknowledgements}

This work was supported by grants of the Moroccan National Center for Scientific and techniques Research (CNRST) to
Ouarda AZDAD. We would like to thank the Local authorities of Health Ministry of Fez as well as all patients participating in this work for their assistance.

\section{Conflict of interest}

The authors declare that they have no conflict of interest.

\section{Funding}

This research received no specific grant from any funding agency in the public, commercial, or not-for-profit sectors.

\section{References}

1. Azdad O, Mejrhit N, Bousfiha A, Chihab Z, Taouda H, Ouahidi I and Aarab L. Reported allergy to milk species in schoolchildren of Fez-Meknes Region and its relationship to life environment. Turk J Immunol 2016; 4(3):30-6.

2. Ouahidi I, Ouaazizi C, Mejrhit N, Azdad O and Aarab L. Molecular characterization of Amandin, an Allergen from Almond (Prunus dulcis) and the Effect of Heat and Enzymatic Treatments on Human IgE and Rabbit IgG Sensitivity to Almond Allergens. Turk J Immunol 2017; 5(1):20-30.

3. Mejrhit N, Azdad O and Aarab L. Evaluation of the IgE reactivity of common pandora parvalbumin in a Moroccan population and action of heating and enzymatic treatments. Food Agric Immunol 2017a; 1-12.

4. Azdad O, Mejrhit N, El Kabbaoui M, Chda A, Ouahidi I, Tazi A, Bencheikh R and Aarab L. Effect of heating and enzymatic hydrolysis on casein cow milk sensitivity in Moroccan population. Food Agric Immunol 2017; DOI: 10.1080/09540105.2017.1391179

5. Wal JM, Bernard H, Creminon C, Hamberger C, David B and Peltre G. Cow's milk allergy: the humoral immune response to eight purified allergens. Adv Exp Med Biol 1995; 371:879.

6. Docena GH, Fernandez R, Chirdo FG and Fossati CA. Identification of casein as the major allergenic and antigenic protein of cow's milk. Allergy 1996; 51(6):412-6.

7. Schulmeister U, Hochwallner H, Swoboda I, Focke-Tejkl M, Geller B, Nystrand M, ... and Niggemann, B. Cloning, expression, and mapping of allergenic determinants of $\alpha$ S1-casein, a major cow's milk allergen. J Immunol 2009; 182(11):7019-29.

8. Selo I, Clement G, Bernard H, Chatel JM, Creminon C, Peltre G and Wal JM. Allergy to bovine b-lactoglobulin: specificity of human IgE to tryptic peptides. Clin Exp Allergy 1999; 29(8):1055-63.

9. Järvinen KM, Chatchatee P, Bardina L, Beyer K and Sampson HA. $\operatorname{IgE}$ and IgG binding epitopes on $\alpha$-lactalbumin and $\beta$-lactoglobulin in cow's milk allergy. Int Arch Allergy Imm 2001; 126(2):111-8.

10. Host A, Husby S, Gjesing B, Larsen JN and Løwenstein H. Prospective estimation of $\mathrm{IgG}$, IgG subclass and $\mathrm{IgE}$ antibodies to dietary proteins in infants with cow milk allergy. Allergy 1992; 47(3):218-29.

11. Permyakov EA and Berliner LJ $\alpha$-Lactalbumin: structure and function. FEBS letters 2000; 473(3):269-74.

12. De Wit JN. Nutritional and functional characteristics of whey proteins in food products. J Dairy Sci 1998; 81(3):597-608.

13. Rytkönen J, Karttunen TJ, Karttunen R, Valkonen KH, Jenmalm MC, Alatossava T, ... and Kokkonen J. Effect of heat denaturation on beta-lactoglobulin-induced gastrointestinal sensitization in rats: 
Denatured $\beta$ LG induces a more intensive local immunologic response than native $\beta L$ L. Pediatr Allergy Immu 2002; 13(4):269-77.

14. Ehn BM, Ekstrand B, Bengtsson U and Ahlstedt S. Modification of $\mathrm{IgE}$ binding during heat processing of the cow's milk allergen $\beta$-lactoglobulin. J Agr Food Chem 2004; 52(5):1398-403.

15. Peyron S, Mouécoucou J, Frémont S, Sanchez C, Gontard N. Effects of heat treatment and pectin addition on beta-lactoglobulin allergenicity. J Agr Food Chem 2006; 54:5643-50.

16. Bu GH, Luo YK, Zheng Z, Zheng H. Effect of heat treatment on the antigenicity of bovine $\alpha$-lactalbumin and $\beta$-lactoglobulin in whey protein isolate. Food Agric Immunol 2009; 20:195-206.

17. Ouahidi I, El Hamsas AEY and Aarab L. Modulation of egg white protein allergenicity under physical and chemical treatments. Food Agric Immunol 2011; 22(1):57-68.

18. Bousfiha A and Aarab L. Effect of heat and enzymatic treatments on human $\operatorname{IgE}$ and rabbit IgG sensitivity to white bean allergens. Iran J Allergy Asthm 2013; 12(4):304.

19. Mejrhit N, Azdad O, El Kabbaoui M, Ouahidi I, Tazi A, and Aarab, L. Sensitivity of Moroccans to sardine parvalbumin and effect of heating and enzymatic treatments. Food Agric Immunol 2017; 28(6):1362-73.

20. Manderson GA, Hardman MJ and Creamer LK. Effect of heat treatment on bovine $\beta$-lactoglobulin $\mathrm{A}, \mathrm{B}$, and $\mathrm{C}$ explored using thiol availability and fluorescence. J Agr Food Chem 1999; 47(9):3617-27.

21. Nowak-Wegrzyn A and Fiocchi A. Rare, medium, or well done? The effect of heating and food matrix on food protein allergenicity. Curr Opin Allergy Clin Immunol 2009; 9(3):234-7.
22. Mejrhit N, Azdad O, Chda A, El Kabbaoui M, Bousfiha A, Bencheikh R, ... and Aarab L. Evaluation of the sensitivity of Moroccans to shrimp tropomyosin and effect of heating and enzymatic treatments. Food Agric Immunol 2017b; 28(6):969-80.

23. Bloom KA, Huang FR, Bencharitiwong R, Bardina L, Ross A, Sampson HA and Nowak-Węgrzyn A. Effect of heat treatment on milk and egg proteins allergenicity. Pediatr Allergy Immu 2014; 25(8):740-6.

24. Xu Q, Shi J, Yao M, Jiang M and Luo Y. Effects of heat treatment on the antigenicity of four milk proteins in milk protein concentrates. Food Agric Immunol 2016; 27(3):401-13.

25. Lee HS, Kim MN, Hong JY, Heo WI, Kim KW, Sohn MH, ... and Park JW. The effect of heat treatment or hydrolysis on cow's milk protein distributions and antigenicities. Allergy Asthma Res Dis 2014; 2(4):259-65.

26. Gámez C, Zafra MP, Sanz V, Mazzeo C, Ibáñez MD, Sastre J and del Pozo V. Simulated gastrointestinal digestion reduces the allergic reactivity of shrimp extract proteins and tropomyosin. Food Chem 2015; 173:475-81.

27. Kim SB, Ki KS, Khan MA, Lee WS, Lee HJ, Ahn BS and Kim HS. Peptic and tryptic hydrolysis of native and heated whey protein to reduce its antigenicity. J Dairy Sci 2007; 90(9):4043-50.

28. Bertrand-Harb C, Baday A, Dalgalarrondo M, Chobert JM and Haertle T. Thermal modifications of structure and codenaturation of a-lactalbumin and b-lactoglobulin induce changes of solubility and susceptibility to proteases. Nahrung 2002; 46(4):283-9. 